\title{
Devonian pearls and ammonoid-endoparasite co-evolution
}

\author{
Kenneth De Baets, Christian Klug, and Dieter Korn \\ Acta Palaeontologica Polonica 56 (1), 2011: 159-180 doi: http://dx.doi.org/10.4202/app.2010.0044
}

Raised shell projections on the inner shell walls that form pits on the internal moulds of Devonian ammonoids have been known for several decades. New specimens from Morocco reveal novel details of these structures; most, if not all, of which consist of a capsule of ammonoid shell that covers tiny tubes attached to the outer (= lateral or ventral) shell wall from the inside. In accordance with comparable Recent occurrences of similar structures in molluscs, we use the term "pearls" for these structures and the pits they form on the internal moulds. The nature of these encapsulated tubes is described and discussed. Because of the presence of these tubes inside the pearls, pearl arrangement, and their similarity to Recent mollusc occurrences, the tubes are interpreted as traces of parasitoses. The pearls and pits were grouped into five types based on differences in morphology, size, and arrangement. Then, having used these traits to perform a simple cladistic analysis, the resulting cladogram was compared to the phylogeny of ammonoids. Based on this comparison, it appears likely that the parasites underwent a co-evolution with the ammonoids, which lasted 10 to $15 \mathrm{Ma}$. Patterns of evolutionary events include co-speciation, "drowning on arrival" (end of parasite lineage near base of a new host clade), and "missing the boat" (parasite lineage does not adapt to a new host clade, thus not evolving a new parasite clade). Because of the lack of fossilised soft tissue, only speculations can be made about the systematic affiliation of the parasites, their life-cycle, infection strategy, and ecological framework. Some co-occurring bivalves also have pits reminiscent to structures caused by trematodes in Recent forms. Based on the available information, the tubes are interpreted as artefacts of trematode infestations, which, if correct, would extend the fossil record of parasitic trematodes into the Early Devonian.

Key words: Ammonoidea, Trematoda, parasite, pearl, co-evolution, Devonian, Morocco, Algeria, Germany.

Kenneth De Baets [kenneth.debaets@pim.uzh.ch] and Christian Klug [chklug@pim.uzh.ch ], Paläontologisches Institut und Museum, Universität Zürich, Karl Schmid-Strasse 4, CH-8006 Zürich, Switzerland; Dieter Korn [dieter.korn@mfn-berlin.de], Museum für Naturkunde, Leibniz Institute at the Humboldt University Berlin, Invalidenstraße 43, D-10 115 Berlin, Germany. 
This is an open-access article distributed under the terms of the Creative Commons

Attribution License (for details please see creativecommons.org), which permits unrestricted use, distribution, and reproduction in any medium, provided the original author and source are credited.

Forif Full text $(1,737.6 \mathrm{kB})$ 